Proceedings of the 11th Polish-Japanese Joint Seminar on Micro and Nano Analysis, Gniew, September 11-14, 2016

\title{
Electrical Properties of $\mathrm{BaCeO}_{3}$-Based Electrolytes for use in Dual Protonic Ceramic-Solid Oxide Fuel Cells
}

\author{
R. GAWEL* AND K. PRZYBYlSKi \\ AGH University of Science and Technology, Faculty of Materials Science and Ceramics, \\ Al. A. Mickiewicza 30, 30-059 Krakow, Poland
}

\begin{abstract}
Bulk samples consisting of $\mathrm{BaCe}_{0.85} \mathrm{Y}_{0.15} \mathrm{O}_{3-\delta}$ (BCY15) and $\mathrm{Ce}_{0.85} \mathrm{Y}_{0.15} \mathrm{O}_{2-\delta}$ (YDC15) compounds, mixed together in different ratios, were studied as potential electrolytes in dual protonic ceramic-solid oxide fuel cells and compared with non-composite BCY15 and YDC15. The microstructures of the sintered materials indicate that BCY15 exhibits the largest grains, whereas composites have greater visible porosity than the non-composite samples. From X-ray diffraction studies it follows that BCY15 and YDC15 consist mainly of one phase, whereas the composites are two-phase materials. Electrochemical impedance spectroscopy studies at different temperatures show that the composite materials are capable of conduction the order of $10^{-3} \mathrm{~S} / \mathrm{cm}$ at temperatures above $500{ }^{\circ} \mathrm{C}$ in a hydrogen-containing atmosphere. Furthermore, activation energy values of the conductivity determined for the composites in air atmosphere are between those obtained for BCY15 $\left(E_{a}=0.590 \pm 0.017 \mathrm{eV}\right)$ and YDC15 $\left(E_{a}=\right.$ $1.132 \pm 0.008 \mathrm{eV}$ ). From this it follows that both phases of the composites influence the electrical conductivity of the materials. In conclusion, BCY15 and the BCY15-YDC15 composites show promise for future use as electrolytes in dual protonic ceramic-solid oxide fuel cells.
\end{abstract}

DOI: 10.12693/APhysPolA.131.1361

PACS/topics: composites, electrolytes, ceramics, electrochemistry

\section{Introduction}

Ceramic fuel cells that operate at elevated temperatures have been studied for many years as potential alternative energy sources. Initially, yttria-stabilized zirconia (YSZ) compounds were used as electrolytes in socalled solid oxide fuel cells (SOFCs) due to the significant oxide ion $\left(\mathrm{O}^{2-}\right)$ conductivity of such materials around $1000^{\circ} \mathrm{C}[1,2]$. Later, it was determined that cerium dioxide $\left(\mathrm{CeO}_{2}\right)$ doped with trivalent oxides $\left(\mathrm{M}_{2} \mathrm{O}_{3} ; \mathrm{M}=\mathrm{Y}\right.$, $\mathrm{Sc}, \mathrm{Gd}$, etc.) exhibit significant $\mathrm{O}^{2-}$ conduction in the temperature range $600-800^{\circ} \mathrm{C}[3-5]$. Pure cerium dioxide exhibits mixed ionic/electronic conductivity at elevated temperatures [6-8]. However, the addition of trivalent oxides increases oxygen vacancy concentration in the material, according to the Kröger-Vink notation [9] presented in Eq. (1):

$$
\mathrm{M}_{2} \mathrm{O}_{3} \stackrel{\mathrm{CeO}_{2}}{\longrightarrow} 2 \mathrm{M}_{\mathrm{Ce}}^{\prime}+3 \mathrm{O}_{\mathrm{O}}^{X}+V_{\mathrm{O}}^{\bullet \bullet} \text {. }
$$

This, in turn, leads enhances $\mathrm{O}^{2-}$ diffusion through the compound, in accordance with the following equilibrium:

$$
\mathrm{O}_{\mathrm{O}}^{X} \leftrightarrow \frac{1}{2} \mathrm{O}_{2}(\mathrm{~g})+2 \mathrm{e}^{\prime}+V_{\mathrm{O}}^{\bullet \bullet} .
$$

Thanks to $\mathrm{CeO}_{2}$-based electrolytes, it is possible to produce SOFCs that are capable of operating in a lower temperature range $\left(600-800^{\circ} \mathrm{C}\right)$ than initially-designed SOFCs. These fuel cells are called intermediate temperature solid oxide fuel cells (IT-SOFCs). Fuel cell stacks consisting of IT-SOFCs units can be manufactured with less expensive components compared to those built with

\footnotetext{
*corresponding author; e-mail: ragaw@agh.edu.pl
}

high temperature SOFCs units, e.g. IT-SOFCs stacks can use metallic interconnect materials. Furthermore, Iwahara et al. discovered that perovskite-based compounds are capable of proton conduction in a hydrogencontaining atmosphere at elevated temperatures [10]. This leads to the possibility of creating IT-SOFCs that generate power by conducting protons $\left(\mathrm{H}^{+}\right)$from the anode to the cathode, instead of $\mathrm{O}^{2-}$ ions from the cathode to the anode. These fuel cells with perovskite-based electrolytes were named protonic ceramic fuel cells (PCFCs), or proton conducting solid oxide fuel cells $\left(\mathrm{SOFCs}-\mathrm{H}^{+}\right)$. The ability of these materials to conduct $\mathrm{H}^{+}$ions can be explained by the formation of hydroxide species $\left(\mathrm{OH}^{\bullet}\right)$ in the compound, which enables proton diffusion through the interstitial area of the material via the Grotthuss ("hopping") mechanism [11, 12]. According to this mechanism, protons migrate by jumping from one interstitial site to the next, breaking and forming new hydroxide ions with each jump. This conduction in hydrogen or water vapour containing atmospheres can be expressed as

$$
\begin{aligned}
& 1 / 2 \mathrm{H}_{2}+\mathrm{O}_{\mathrm{O}}^{X} \rightarrow \mathrm{OH}_{\mathrm{O}}^{\bullet}+\mathrm{e}^{\prime}, \\
& \mathrm{H}_{2} \mathrm{O}+V_{\mathrm{O}}^{\bullet \bullet}+\mathrm{O}_{\mathrm{O}}^{X} \rightarrow 2 \mathrm{OH}_{\mathrm{O}}^{\bullet} .
\end{aligned}
$$

Among several perovskite oxides doped with trivalent cations $\left(\mathrm{M}^{3+}=\mathrm{Y}^{3+}, \mathrm{Sc}^{3+}, \mathrm{Yb}^{3+}, \mathrm{Gd}^{3+}\right.$, etc. $), \mathrm{BaCeO}_{3}$ doped with $\mathrm{Y}^{3+}(\mathrm{BCY})$ has shown very promising electrical properties for application as a PCFCs electrolyte [1315]. However, the chemical instability of such materials in the presence of $\mathrm{CO}_{2}[16,17]$ limits the use of hydrocarbon fuels in the system.

Both PCFCs and SOFCs have several advantages, e.g. clean chemical to electrical energy conversion, quiet vibration-free operation and relatively high efficiency (50-60\%). However, in both cases, overall system effi- 
ciency is lowered due to the formation of water vapour $\left(\mathrm{H}_{2} \mathrm{O}\right)$ at one of the electrodes during fuel cell operation. A solution to this drawback was proposed by the Innovative Dual mEmbrAne fueL Cell (IDEAL-Cell) project (2008-2011). The idea behind the project was to combine the anode/electrolyte (anode compartment) of a PCFC with the cathode/electrolyte (cathode compartment) of a SOFC by means of a porous central membrane (CM). A schematic representation of this dual protonic ceramic-solid oxide fuel cell (PCFC-SOFC) is illustrated in Fig. 1 [18]. From this figure it follows that the device generates electrical energy by simultaneously conducting protons through the anode compartment and oxide ions through the cathode compartment. These ionic species meet in the CM, recombine and form water vapour, which is then evacuated through open porosity.

\section{IDEAL Cell}

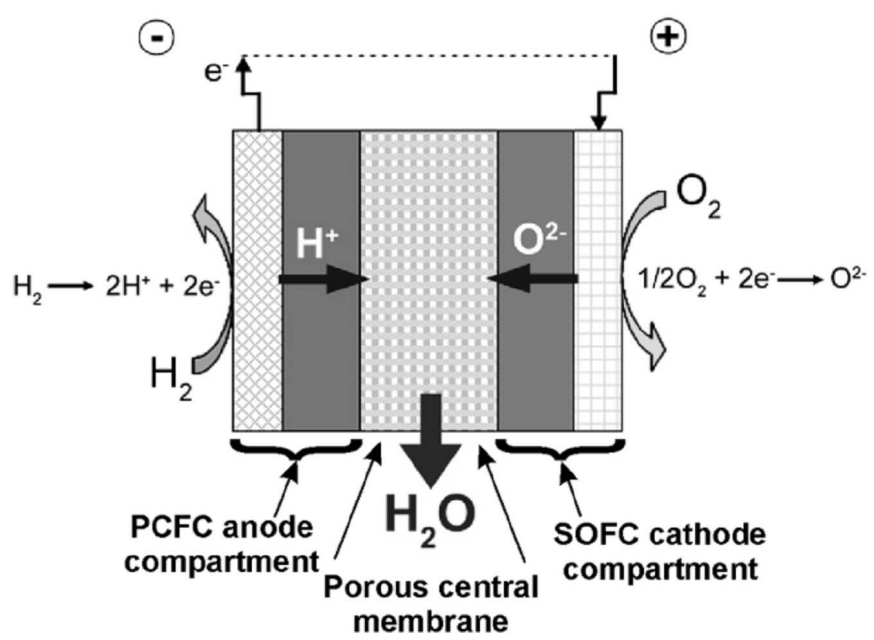

Fig. 1. Schematic representation of a dual PCFCSOFC [18, 19].

Barium cerate doped with 15 at.\% $\mathrm{Y}^{3+}$ (BCY15) was chosen as the protonic ceramic fuel cell electrolyte in the system, because previous research suggested that this amount of doping ensures optimal proton conductivity among BCY compounds [20]. On the other hand, $\mathrm{CeO}_{2}$ doped with 15 at.\% $\mathrm{Y}_{2} \mathrm{O}_{3}$ (YDC15) was selected as the solid oxide fuel cell electrolyte due to its compatibility with BCY15 [19], as the former is a decomposition product of the latter. After prolonged exposure to significantly high temperatures (e.g. sintering temperatures $\geq 1450{ }^{\circ} \mathrm{C}$ ), BCY15 decomposes into YDC15, as expressed by Eq. (5):

$$
\begin{aligned}
& \mathrm{BaCe}_{0.85} \mathrm{Y}_{0.15} \mathrm{O}_{3-\delta} \leftrightarrow \\
& \mathrm{Ba}_{1-x} \mathrm{Ce}_{0.85} \mathrm{Y}_{0.15} \mathrm{O}_{3-x-\delta}+x \mathrm{BaO} .
\end{aligned}
$$

However, the key component of the PCFCs-SOFCs is the central membrane, which must exhibit significant ionic conductivity for both species $\left(\mathrm{H}^{+}\right.$and $\left.\mathrm{O}^{2-}\right)$, allow the two species to meet and recombine, and have a sufficient amount of open porosity for easy $\mathrm{H}_{2} \mathrm{O}$ evacuation [18, 21].
Research carried out within the framework of the IDEALCell project has confirmed that water vapour can form inside and be evacuated from a composite material consisting of BCY15 and YDC15. The goal of this paper is to determine the electrical conductivity of BCY15YDC15 composites in hydrogen and oxygen-containing atmospheres and compare the results with those obtained for non-composite BCY15 and YDC15 samples.

\section{Experimental procedure}

Precursors of BCY15 and YDC15 were synthesized via co-precipitation using the following substances as received from suppliers:

- barium nitrate $\mathrm{Ba}\left(\mathrm{NO}_{3}\right)_{2}$ (99.9\%), Quality Chemicals, Barcelona, Spain,

- cerium nitrate $\mathrm{Ce}\left(\mathrm{NO}_{3}\right)_{2}(\geq 99.5 \%)$, ALTICHEM, Cergy-Pontoise, France,

- yttrium nitrate $\mathrm{Y}\left(\mathrm{NO}_{3}\right)_{3}(99.99 \%)$, ALTICHEM, Cergy-Pontoise, France,

- ammonium carbonate $\left(\mathrm{NH}_{4}\right)_{2} \mathrm{CO}_{3}(99.5 \%), \mathrm{AL}$ TICHEM, Cergy-Pontoise, France.

After the nitrates along with the ammonium carbonate precipitating agent were mixed together in the appropriate ratios, the obtained BCY15 and YDC15 precursors were dried and grinded. The BCY15 precursor then underwent heat treatment at $1000^{\circ} \mathrm{C}$ for $6 \mathrm{~h}$ (heating/cooling rate: $100^{\circ} \mathrm{C} / \mathrm{h}$ ), whereas the YDC15 precursor received $1 \mathrm{~h}$ heat treatment at $900^{\circ} \mathrm{C}$ (heating/cooling rate: $300^{\circ} \mathrm{C} / \mathrm{h}$ ). The nominal compositions of the obtained BCY15 and YDC15 compounds were, according to investigations carried out in the framework of the IDEAL-Cell project, $\mathrm{BaCe}_{0.85} \mathrm{Y}_{0.15} \mathrm{O}_{2.925}$ and $\mathrm{Ce}_{0.85} \mathrm{Y}_{0.15} \mathrm{O}_{2.925}$, respectively. In both cases, the prepared oxides underwent wet deagglomeration, drying and then sieving. Finally, the compounds were thermally treated at $600^{\circ} \mathrm{C}$, resulting in the finished products (BCY15 and YDC15 powders).

The obtained non-composite powders were then mixed together for $24 \mathrm{~h}$ in the ratios presented in Table I via milling using zirconia $\left(\mathrm{ZrO}_{2}\right)$ balls and $20 \mathrm{ml}$ of isopropanol in polyethylene terephthalate (PET) bottles. Afterwards, the mixtures in the appropriate bottles were frozen in liquid nitrogen and, finally, separated from the $\mathrm{ZrO}_{2}$ balls via sieving through a $53 \mu \mathrm{m}$ mesh. Each composite powder was then mixed together with polyvinyl alcohol (PVA) in the amount of $1 \mathrm{wt} \%$ via the previously described $24 \mathrm{~h}$ ball milling process in order to improve mechanical properties of pellets obtained from pressing the above-mentioned powders.

The obtained powders were pressed at 50 bar in order to form pellets. After isostatic pressing at $250 \mathrm{MPa}$, the pellets were annealed at $500{ }^{\circ} \mathrm{C}$ and sintered at $1500^{\circ} \mathrm{C}$ for $2 \mathrm{~h}$ in the case of BCY15, B90Y10 and B70Y30 and for $4 \mathrm{~h}$ in the case of the remaining samples (heating/cooling 
TABLE I

Designation of the studied composite powders and volume fractions of the initial BCY15 and YDC15 powders used to obtain the materials.

\begin{tabular}{c|c}
\hline \hline Symbol & Composition [vol.\%] \\
\hline B90Y10 & $90 \% \mathrm{BaCe}_{0.85} \mathrm{Y}_{0.15} \mathrm{O}_{3-\delta}+10 \% \mathrm{Ce}_{0.85} \mathrm{Y}_{0.15} \mathrm{O}_{2-\delta}$ \\
B70Y30 & $70 \% \mathrm{BaCe}_{0.85} \mathrm{Y}_{0.15} \mathrm{O}_{3-\delta}+30 \% \mathrm{Ce}_{0.85} \mathrm{Y}_{0.15} \mathrm{O}_{2-\delta}$ \\
Y70B30 & $30 \% \mathrm{BaCe}_{0.85} \mathrm{Y}_{0.15} \mathrm{O}_{3-\delta}+70 \% \mathrm{Ce}_{0.85} \mathrm{Y}_{0.15} \mathrm{O}_{2-\delta}$ \\
Y80B20 & $20 \% \mathrm{BaCe}_{0.85} \mathrm{Y}_{0.15} \mathrm{O}_{3-\delta}+80 \% \mathrm{Ce}_{0.85} \mathrm{Y}_{0.15} \mathrm{O}_{2-\delta}$ \\
Y90B10 & $10 \% \mathrm{BaCe}_{0.85} \mathrm{Y}_{0.15} \mathrm{O}_{3-\delta}+90 \% \mathrm{Ce}_{0.85} \mathrm{Y}_{0.15} \mathrm{O}_{2-\delta}$
\end{tabular}

rate: $\left.3{ }^{\circ} \mathrm{C} / \mathrm{min}\right)$. It was assumed that the partial $\mathrm{BCY} 15$ decomposition, presented in Eq. (5), would be less significant during the sintering of the composite samples with larger amounts of YDC15 than BCY15. The morphology of the obtained bulk samples were studied by scanning electron microscopy (SEM), whereas the phase composition of the samples was determined via X-ray diffraction (XRD). Additionally, grain size distribution studies were carried out via image analysis of the obtained SEM microphotographs using the computer programme Aphelion ${ }^{\mathrm{TM}}$ Lab.

Before electrochemical analysis the surfaces of the samples were polished by sandpaper of 200, 250, and 800 gradation. Afterwards, platinum paste was deposited on the both sides of the samples using the screen-printing method. After drying the paste on each side for around $2 \mathrm{~h}$ at $100^{\circ} \mathrm{C}$, the platinum was fired at $900^{\circ} \mathrm{C}$ for $10 \mathrm{~min}$ (heating rate: $2^{\circ} \mathrm{C} / \mathrm{min}$; cooling rate: $5^{\circ} \mathrm{C} / \mathrm{min}$ ). The obtained $\mathrm{Pt} /$ sample $/ \mathrm{Pt}$ cells were then inserted into a furnace containing an element connected to an AutoLab PGSTAT302N frequency response analyzer. This system enabled performing electrochemical impedance spectroscopy (EIS) measurements at different temperatures. These measurements were carried out for each sample in the frequency range $1 \mathrm{MHz}-1 \mathrm{mHz}$ between 200 and $500^{\circ} \mathrm{C}$ with the temperature increasing in steps of $50^{\circ} \mathrm{C}$ in both $\mathrm{Ar}-5 \% \mathrm{H}_{2}$ and air atmospheres.

After measuring the resistance in the above-mentioned conditions, the total electrical conductivity values can be calculated using Pouillet's law

$$
R=\rho l / S,
$$

where $R$ - resistance of the material $[\Omega]$ (determined in this case as the sum of grain interior and grain boundary resistance $\left.R=R_{g i}+R_{g b}\right), \rho$ - electrical resistivity of the solid $[\Omega \mathrm{cm}], l$ - length carrying a uniform current $[\mathrm{cm}]$ (in this case: thickness of the studied sample), $S$ - bounded area in which the current is carried $\left[\mathrm{cm}^{2}\right]$ (in this case: surface area of the platinum electrode). By definition electrical conductivity is the inverse of resistivity $(\sigma=1 / \rho[\mathrm{S} / \mathrm{cm}])$ and can thus be determined as

$$
\sigma=(l / S) R .
$$

In order to determine the activation energies $\left(E_{a}[\mathrm{eV}]\right)$ for electrical conductivity of the samples, linear regression of the total conduction values, obtained at different temperatures, was performed. Then, the electrical conduction activation energies of each sample in both atmospheres were calculated using the following Arrhenius correlation [22]:

$$
\sigma T=A \exp \left(E_{a} / k T\right),
$$

where $A$ - material constant containing the carrier concentration term $\left[\mathrm{S} \mathrm{cm}^{-1} \mathrm{~K}\right], k$ - the Boltzmann constant $[\mathrm{eV} / \mathrm{K}], T$ - absolute temperature at which the impedance measurements were carried out $[\mathrm{K}]$.

\section{Results and discussion}

A comparison of the morphologies of BCY15, B70Y30, Y70B30, and Y90B10 determined by SEM analysis is presented in Fig. 2a, Fig. 2b, Fig. 2c, and Fig. 2d, respectively. In these microphotographs the lowest amount of visible porosity and largest grain sizes were observed in the case of BCY15. This is also confirmed by the image analysis pertaining to grain size distribution, the results of which are presented in Table II. As for the B70Y30 sample, Fig. 2b indicates that sintering for $2 \mathrm{~h}$ at $1500{ }^{\circ} \mathrm{C}$ is insufficient for significant grain growth and porosity elimination in a BCY15-YDC15 composite material. The remaining samples sintered for $4 \mathrm{~h}$ at $1500^{\circ} \mathrm{C}$ (Fig. 2c and Fig. 2d) still exhibit a larger amount of open porosity and smaller grains than non-composite BCY15 sample, yet seem to have achieved greater density than the B70Y30 material. However, it must be taken into account that some amounts of open porosity are necessary for water vapour evacuation from the central membrane in a dual PCFC-SOFC fuel cell.

TABLE II

Grain size $[\mu \mathrm{m}]$ distribution obtained by image analysis of the samples sintered at $1500^{\circ} \mathrm{C}$.

\begin{tabular}{c|c|c|c}
\hline \hline Material & Smallest & Largest & Median $\left(d_{50}\right)$ \\
\hline BCY15 & 0.437 & 9.600 & 2.378 \\
B70Y30 & 0.236 & 2.476 & 0.322 \\
Y70B30 & 0.266 & 4.180 & 1.547 \\
YDC15 & 0.747 & 5.162 & 1.002
\end{tabular}
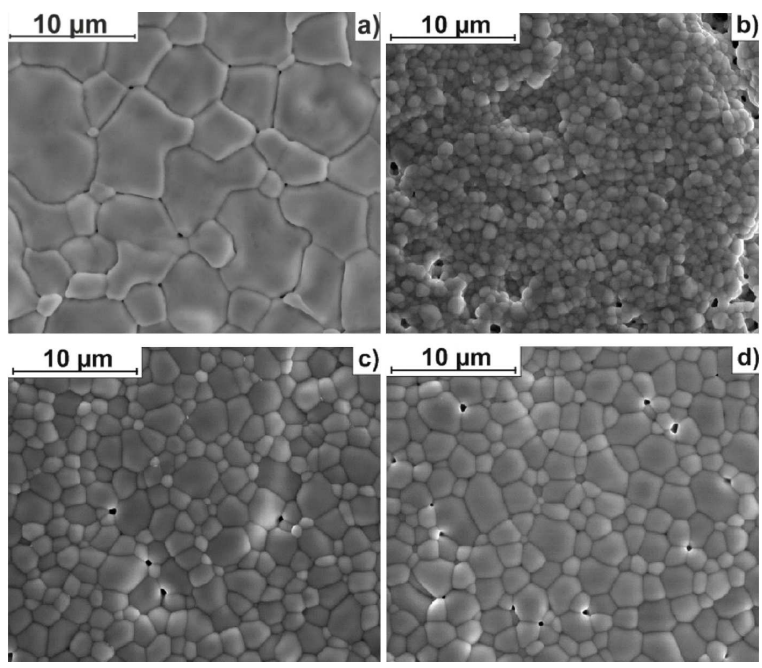

Fig. 2. SEM microphotographs of (a) BCY15, (b) B70Y30, (c) Y70B30 and (d) Y90B10 bulk samples obtained from sintering at $1500^{\circ} \mathrm{C}$. 


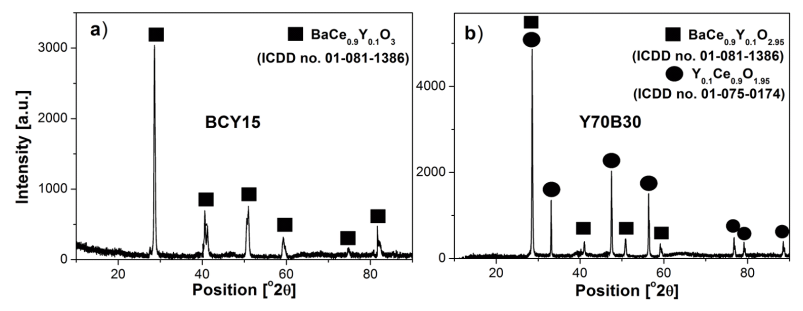

Fig. 3. XRD diffraction patterns of the (a) BCY15 and (b) Y70B30 samples obtained at $1500^{\circ} \mathrm{C}$.
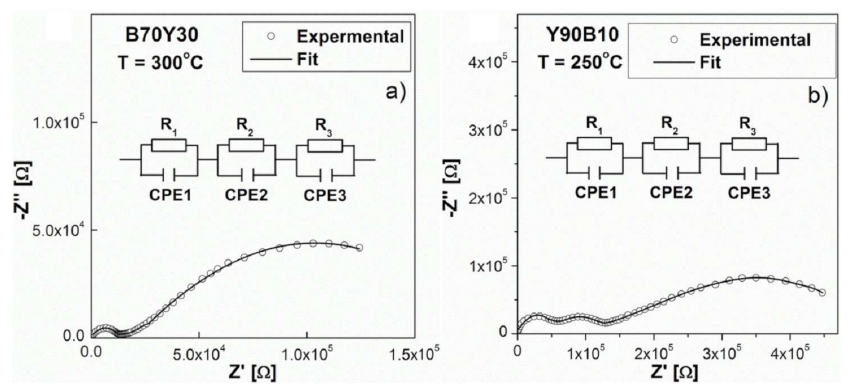

Fig. 4. Impedance spectra obtained from EIS analysis of (a) B70Y30 at $300^{\circ} \mathrm{C}$ in air and (b) Y90B10 at $250^{\circ} \mathrm{C}$ in $\mathrm{Ar}-5 \% \mathrm{H}_{2}$ atmosphere.

The XRD studies of selected samples shown in Fig. 3a and Fig. 3b indicate that sintered samples were obtained without significant amounts of impurities. One $\mathrm{BaCeO}_{3}-$ based phase was detected in the case of BCY15 (Fig. 3a), whereas both $\mathrm{BaCeO}_{3}$ and $\mathrm{CeO}_{2}$-based phases were determined in the Y70B30 composite sample.

Impedance spectra obtained from EIS analysis of B70Y30 at $300^{\circ} \mathrm{C}$ and $\mathrm{Y} 90 \mathrm{~B} 10$ at $250^{\circ} \mathrm{C}$ are illustrated in Fig. 4a and Fig. 4b, respectively. In both cases, three different arcs, i.e. a high frequency $(\mathrm{HF})$, intermediate frequency (IF) and low frequency (LF) arc, were determined. An appropriate equivalent circuit, consisting of three parallel resistor/constant phase elements connected in series, was then used to fit theoretical values to the experimentally obtained data. The capacitance values were used to differentiate the conduction mechanisms in the materials. Capacitance values of the HF arcs, received at different temperatures in both air and $\mathrm{Ar}-5 \% \mathrm{H}_{2}$ atmospheres, were determined between $10^{-11}$ and $10^{-8} \mathrm{~F}$, whereas values in the range of $10^{-9}-10^{-6} \mathrm{~F}$ were obtained for the IF arcs. The ratios between the capacitance values $\left(C_{1} / C_{2}\right)$ were then calculated. According to the brick layer model, if the $C_{1} / C_{2}$ ratios are comparable to the ratios between grain boundary thickness and grain size $(d / D)$, then it can be assumed that the $\mathrm{HF}$ and IF arcs correspond to grain interior and grain boundary conduction, respectively. The high frequency (HF) to intermediate frequency (IF) capacitance ratio $\left(C_{1} / C_{2}\right)$, obtained at different temperatures in both $\mathrm{Ar}-$ $5 \% \mathrm{H}_{2}$ and air atmosphere for the studied samples, range from the order of $10^{-2}$ to $10^{-5}$ (a significant correction factor should also be taken into account due to the large grain size distributions indicated by the results shown in Table II). This is characteristic for grain interior and grain boundary conductivity, seeing as grain sizes of the materials studied in this dissertation are in the $\mu \mathrm{m}$ range (see Table II) and grain boundary thickness of ceramic materials is usually in the $1-10 \mathrm{~nm}$ range [23-26]. The capacitance values obtained in this paper contradict the results obtained in [27] for a $\mathrm{BaCeO}_{3}-\mathrm{CeO}_{2}$-based composite material. In that work, the IF capacitance values were more similar to those obtained for the HF arc, which suggests that the IF arc does not pertain to grain boundary conduction. However, the results in this paper seem to indicate that an additional conduction mechanism does not take place inside the BCY15-YDC15 composites. Instead, it appears that the arcs obtained in this work can be interpreted using the Bauerle circuit equivalent for ceramic electrolytes [28], where the HF, IF and LF arcs correspond to grain interior, grain boundary, and electrode/electrolyte interface conductivity, respectively.

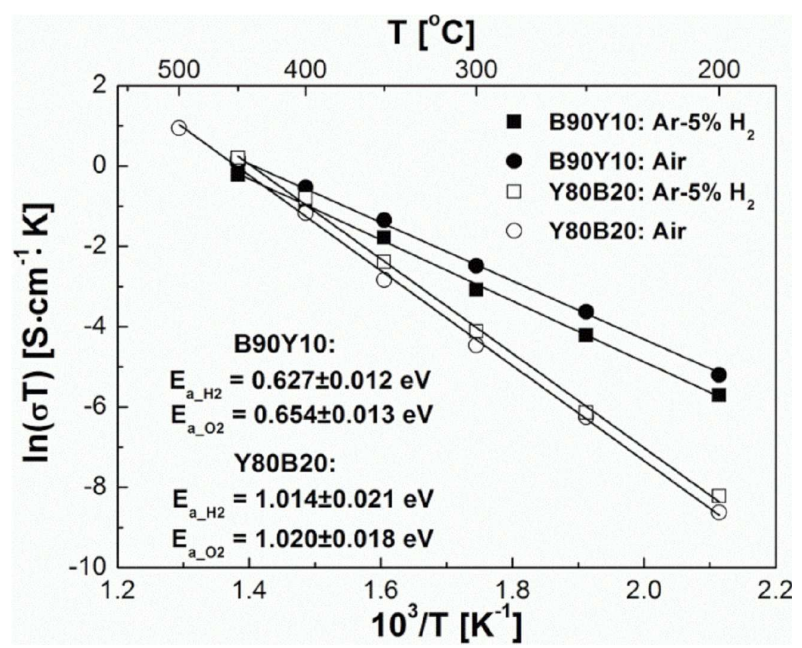

Fig. 5. Temperature dependence of total conductivity obtained in $\mathrm{Ar}-5 \% \mathrm{H}_{2}$ and air atmospheres for B90Y10 in the temperature range $200-450^{\circ} \mathrm{C}$ and Y80B20 in the temperature range $200-500^{\circ} \mathrm{C}$.

A comparison of the Arrhenius correlations of two selected samples between total electrical conductivity values, determined from the EIS measurements performed in this work, and temperature is presented in Fig. 5. From this figure it follows that in the case of both samples the electrical conduction values obtained in the $\mathrm{Ar}-5 \% \mathrm{H}_{2}$ gas mixture are higher than those determined in air in the temperature range $200-500^{\circ} \mathrm{C}$. However, the values become gradually more similar as the temperature increases. This is because the activation energy $\left(E_{a}\right)$ for electrical conductivity of a given composite sample is lower in the $\mathrm{H}_{2}$-containing atmosphere than in air. The difference between the activation energies of conduction in different atmospheres is greater in the case of the B90Y10 sample $(0.056 \mathrm{eV})$ compared to Y80B20 $(0.006 \mathrm{eV})$. The activation energy values of conduction in the Y80B20 material are also larger than those determined for the B90Y10 sample. 


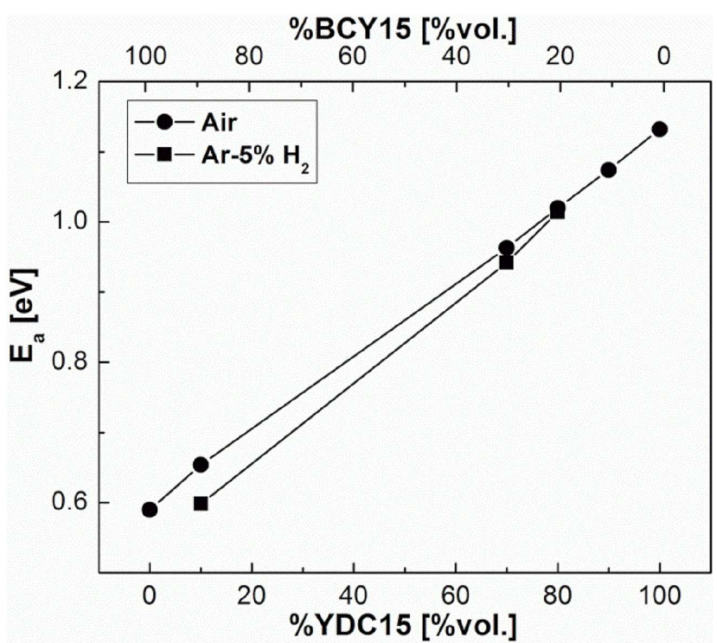

Fig. 6. Correlation between total activation energy of electrical conductivity through a given material in Ar$5 \% \mathrm{H}_{2}$ and air atmosphere and volume fractions of the initial BCY15 and YDC15 powders used to obtain the samples.

A comparison of the electrical conduction activation energies obtained for the samples in both air and $\mathrm{Ar}-$ $5 \% \mathrm{H}_{2}$ gas mixture is presented in Fig. 6. From this figure it follows that the activation energy values in both atmospheres increase along with the amount of YDC15 in the BCY15-YDC15 composite electrolytes. Furthermore, the activation energy values of electrical conduction in $\mathrm{Ar}-5 \% \mathrm{H}_{2}$ atmosphere become gradually more similar to those pertaining to conduction in air as the percentage of YDC15 increases. It is also interesting to notice that the correlations between the BCY15/YDC15 content and the activation energy values are almost linear in both cases.

\section{Conclusions}

From the results of the electrical conductivity analysis it can be concluded that each of the two phases present in the composites (based on $\mathrm{BaCeO}_{3}$ and $\mathrm{CeO}_{2}$ ) influences the conduction of both ionic species $\left(\mathrm{H}^{+}\right.$and $\left.\mathrm{O}^{2-}\right)$ inside the materials. Consequently, the activation energies of electrical conductivity determined for all the composites in $\mathrm{H}_{2}$ and $\mathrm{O}_{2}$-containing gas mixtures are between those obtained for the non-composite $\mathrm{BaCe}_{0.85} \mathrm{Y}_{0.15} \mathrm{O}_{3-\delta}$ (BCY15) and $\mathrm{Ce}_{0.85} \mathrm{Y}_{0.15} \mathrm{O}_{2-\delta}(\mathrm{YDC} 15)$ samples $\left(E_{a}=\right.$ $0.590 \pm 0.017 \mathrm{eV}$ and $E_{a}=1.132 \pm 0.008 \mathrm{eV}$ in air, respectively). The results also indicate that the Y70B30, Y80B20, and Y90B10 composite bulk samples, received after sintering for $4 \mathrm{~h}$, are capable of electrical conduction greater than $10^{-3} \mathrm{~S} / \mathrm{cm}$ at temperatures above $500^{\circ} \mathrm{C}$ in both $\mathrm{H}_{2}$ and $\mathrm{O}_{2}$-containing atmospheres. The analysis also suggest that these samples exhibit better conduction in the intermediate temperature range $\left(500-800^{\circ} \mathrm{C}\right)$ than the B90Y10 and B70Y30 composite samples obtained after sintering for $2 \mathrm{~h}$, despite having higher activation energies. This can be attributed to the influence of grain sizes in the polycrystalline materials on the elec- trical conductivity of the samples. It is probable that the porosity of the sintered samples also affects the conductivity values. However, it is difficult to determine the exact correlation between porosity of the studied samples and their electrical conductivity, because closed pores inside the materials also affect the electrical properties of semiconductors. Further studies should be carried out to determine the sintering conditions that ensure the grain size and amount of open porosity that enables each of the investigated materials to exhibit optimal electrical conduction, as well as allow for good water vapour evacuation. The combined results obtained in this work suggest that such composite materials would show promise for future use as central membranes in commercial dual PCFCs-SOFCs.

\section{Acknowledgments}

The research leading to these results has received funding from the European Union's Seventh Framework Programme (FP7/2007-2013) under grant agreement No. 213389 .

\section{References}

[1] J.M. Dixon, L.D. LaGrange, U. Merten, C.F. Miller, J.T. Porter II, J. Electrochem. Soc. 110, 276 (1963).

[2] D.W. Strickler, W.G. Carlson, J. Am. Ceram. Soc. 47, 122 (1964).

[3] H.L. Tuller, A.S. Nowick, J. Electrochem. Soc. 122,0 255 (1975).

[4] H. Yahiro, Y. Eguchi, K. Eguchi, H. Arai, J. Appl. Electrochem. 18, 527 (1988).

[5] H. Yahiro, K. Eguchi, H. Arai, Solid State Ion. 36, 71 (1989).

[6] W. Gao, N.M. Sammes, An Introduction to Electronic and Ionic Materials, World Sci. Publ., Singapore 1999.

[7] H.L. Tuller, A.S. Nowick, J. Phys. Chem. Solids 38, 859 (1977).

[8] H.L. Tuller, A.S. Nowick, J. Electrochem. Soc. 126, 209 (1979).

[9] F.A. Kröger, H.J. Vink, in: Solid State Physics, Vol. 3, Eds. F. Seitz, D. Turnbull, Academic Press, Elsevier B.V., Cambridge (MA) 1956, p. 307.

[10] H. Iwahara, T. Esaka, H. Uchida, N. Maeda, Solid State Ion. 3-4, 359 (1981).

[11] K.D. Kreuer, Chem. Mater. 8, 610 (1996).

[12] H. Iwahara, Solid State Ion. 86-88, 9 (1996).

[13] T. Hibino, A. Hashimoto, M. Suzuki, M. Sano, J. Electrochem. Soc. 149, A1503 (2002).

[14] T. Shimura, H. Tanaka, H. Matsumoto, T. Yogo, Solid State Ion. 176, 2945 (2005).

[15] W. Suksamai, I.S. Metcalfe, Solid State Ion. 178, 627 (2007).

[16] N. Zakowsky, S. Williamson, J.T.S. Irvine, Solid State Ion. 176, 3019 (2005).

[17] P. Sawant, S. Varma, B.N. Wani, S.R. Bharadwaj, Int. J. Hydrogen En. 37, 3848 (2012). 
[18] A.S. Thorel, A. Chesnaud, M. Viviani, A. Barbucci, S. Presto, P. Piccardo, Z. Ilhan, D. Vladikova, Z. Stoynov, ECS Trans. 25, 753 (2009).

[19] G. Caboche, J.-F. Hochepied, P. Piccardo, K. Przybylski, R. Ruckdäschel, M.-R. Ardigó, E. Fatome, S. Chevalier, A. Perron, L. Combemale, M. Palard, J. Prazuch, T. Brylewski, ECS Trans. 25, 763 (2009).

[20] G. Chiodelli, L. Malavasi, C. Tealdi, S. Barison, M. Battagliarin, L. Doubova, M. Fabrizio, C. Mortalň, R. Gerbasi, J. Alloy Comp. 470, 477 (2009).

[21] S. Presto, A. Barbucci, M. Viviani, Z. Ilhan, S.A. Ansar, D. Soysal, A. Thorel, J. Abreu, A. Chesnaud, T. Politova, K. Przybylski, J. Prazuch, T. Brylewski, Z. Zhao, D. Vladikova, Z. Stoynov, ECS Trans. 25, 773 (2009).
[22] Z.-X. Lin, Z.-K. Gun, C.-W. Sun, Rapid Ion Conductor - Foundation, Materials, Application, Shanghai Science Technology Press, Shanghai 1983, p. 46 (in Chinese).

[23] W.D. Kingery, J. Am. Ceram. Soc. 57, 1 (1974).

[24] W.D. Kingery, J. Am. Ceram. Soc. 57, 74 (1974).

[25] X. Guo, S. Kim, in: Annual Review of Nano Research, Vol. 2, Eds. G. Cao, C.J. Brinker, World Sci. Publ., Singapore 2008, p. 495.

[26] M.C. Martin, M.L. Mecartney, Solid State Ion. 161, 67 (2003).

[27] M. Khandelwal, A. Venkatasubramanian, T.R.S. Prasanna, P. Gopalan, J. Eur. Ceram. Soc. 31, 559 (2011).

[28] J.E. Bauerle, J. Phys. Chem. Solids 30, 2657 (1969). 